\title{
Comparative Overview of Local Government Legislation in Albanian-speaking Republics
}

\section{Enea Sherifi}

\author{
PhD Candidate, Albanian Institute for European Studies
}

\author{
Doi:10.5901/ajis.2016.v5n3s1p86
}

\section{Abstract}

The Consttution of Albania defines in its Article 108, three units of local power, communes, municipalities and districts. Upon teh amendaments deriving from the new territorial reform, Albania has only 61 municipalities and 12 districts and no commune at all. In the article 5 of the law no. 139/2015 of the Local Self- Governance of the Republic of Albania, it is defined that municipalities and districts are the units of local governance. We have to do with a difference between the definition of the Constitution of Albania and the Law on Local Self- Governance. Therefore a constitutional amendment is needed in order to reflect the legal amendments on the local self-governance. The Republic of Albania approved the law no. 8548 on 11th November 1999 "On the ratification of the European Card of Local Autonomy". Upon this approval, the Card is an internal resource of the law and its implementation from the institutions and individuals is obligatory. Point 4 of the Article 14 of the Law on Local Self- Governance in the Republic of Albania defines that the Units of local self- governance may enter into inter-local collaboration agreements with units of foreign local self-governance units. Before entering in such agreements, these units obtain the opinion of the Ministry of Foreign Affairs. "Law on Local Self- Governance" of the Republic of Kosovo, approved in 2008. The reform on local governance started in 1999/2000, upon the end of the War in Kosovo and settlement of UNMIK Administration. Initially, the organization and functioning of local power was regulated by UNMIK Rule, which had the legal power, and then by the constitution in 2008. The Republic of Kosovo lies in an area of $10908 \mathrm{~km} / 2$ which is divided in 38 administrative units or in 38 communes which extends and act under specific territorial conditions. "Law on Local SelfGovernance" of the Republic of Macedonia defines the communes as units of local self-governance. Another particularity of the Law on Local Self- Governance of the Local Republic of Macedonia is the status given to the city of Skopje as a special unit of local governance, as it is the Capital of the Republic. There are to be done the right legal amendments, in accordance to the legislation of EU and the interstate coordination in order to improve the collaboration in local governance level among the Albanian- speaking states, especially in the economic point of view, but as well as in the cultural and environmental one.

Keywords: decentralization, legislation on local governance, local autonomy, administrative reform, EU legislation on local and regional governance, european governance of local autonomy.

\section{Introduction: The Meaning of Decentralisation}

The thesis aims to make a comparative view of local government in Albanian speaking countries. If we refer to the political vocabulary of the Oxford term local government means a "Government institution that exercises authority in a territorially defined area of the country" * 1 (lain Mc Lean. Political Dictionary. Tirana 2001, page 479)

Decentralization in itself is a process during which authority and responsibility for functions, passes from central government to local government units. Albania Constitution of 1998 stipulated that local authorities are based on the principle of decentralization and that relationship between central and local government are based on autonomy, legitimacy and cooperation *2 (Article 13. Constitution of the Republic of Albania - Law 8417, dated 21/1998)

Local government in Kosovo, Macedonia and Montenegro is achieved under constitutional norms and laws of local government. In the text of Administrative Sciences at the University of Pristina it is stated that "territorial governance, namely governance of territorial units, is a very complex process and can be argued that it consists of many functions, ie activities". *3 (Esat Stavileci: Introduction to Administrative Sciences. Office of textbooks and teaching aids Kosovo. Pristina, 1997, p. 247)

In the municipalities of Presevo and Bujanovac government is carried out pursuant to the Law on Local SelfGovernment of Serbia.

All democratic states consider Local Government as a value of democratic achievements and of particular importance for the political system. In this paper I do a comparative view of local government in Kosovo, Macedonia, Montenegro, Presevo and Bujanovac municipalities located in the southernmost part of Serbia, and in the East of Kosovo. These municipalities with an Albanian majority, are under the Republic of Serbia. In 1992, local authorities organized a referendum on territorial political autonomy and unification with Kosovo. By the referendum 90\% of the 
Albanian population said "yes" to the question posed in that Referendum.

LGUs in Albania are the municipalities and counties. In other Albanian speaking countries LGUs are the communes.

\section{Local Government in the Republic of Albania}

Local Government in Albania is based on the European Charter of Local Self-Government and in particular in Article 3, which stipulates that Local Self-Government denotes the right and the ability of local authorities, within the limits of the law, to regulate and manage a substantial share of public affairs under their own responsibility and in the interests of the local population. * 4 (European Charter of Local Self-Government).

The first law on the organization of local government of pluralistic period is Law 7572, dated 10.06.1992, titled On Organization and Functioning of Local Government * 5 (Summary of Legislation for Institutions of Local Government of the Republic of Albania).

In the process of decentralization of governance reforms, in 2000 was adopted the Law on Territorial and Administrative Division of Local Government Units / LGU.* 6 (Law No. 8652, dated 31.7.2000 "On organization and functioning of local government')

Territorial and administrative division of 2000 generally maintained historical boundaries of municipalities, communes established in 1992. The package of reforms, which set out a framework of decentralization of governance in Albania, was built on the grounds that local government units, which would not have the opportunity to provide the functions and responsibilities delegated to selfgovernance, will use the alternative offered by the Constitution of Republic of Albania and the Law on the Organization and Functioning of Local Government to join with each other, according to the will of the people to govern, or to engage in LGU collaborations.

Laws and guidelines that complemented the framework of fiscal and administrative decentralization, and were prepared to intergovernmental transfers and grants until 2006were drafted based on this assumption. Law on the Organization and Functioning of Local Government defines three types of functions to LGUs: own (exclusive), shared (joint) and delegated functions. Functional analysis of the performance of functions under the drafting of territorial reform in late 2013 showed that only $15 \%$ of local government units out of the total of 373 LGUs had been performed the functions designated by the organic law of local government. By 2014 there was no change in the groups of main categories of own (exclusive) functions, which include:

- Infrastructure and public services;

- Local economic development;

- Social services, cultural and recreational functions,

- $\quad$ Civil security.

Implementation of shared (joint) functions of local governance was associated with many uncertainties regarding the division of powers and finances between different levels of government. The delegation of functions from central government is an instrument used mainly in some functions, such as administration of the registry offices, business registration offices (NRC) and in general expenses to be covered by the state budget. Very few were the cases of delegation of functions and powers between local self government units of the same level or different levels, even in those cases where this has happened they have not been stable over time.

In 2014, Albania undertook and implemented a reform of the administrative and territorial consolidation by adopting the Law "On the territorial and administrative division of local government units in the Republic of Albania", *7 (Law no. 115/2014 dated 31.07.2014, "On the territorial and administrative division) finally settling the issues of fragmentation of local government and decentralization concluding the reform in our country. Today Albania has 61 local government units I municipalities and 12 districts. Districts did not change with the new territorial and administrative division but their constituent structure, municipalities and communes, underwent a radical change. With the new division, districts have in their structure approximately 5 municipalities from 31 local units that were based on the old division. With this reform the role of the district as harmonization of national policies with regional and local ones becomes easier and presumably would be more efficient. In fiscal decentralization indicators, Albania is far behind compared to other countries of South East Europe. It ranks last in the region to the revenues level of local government. In 2014, revenue accounted for 2.1\% of the Gross Domestic Product (GDP), while fiscal revenues accounted for $1 \%$ of GDP. Only $0.22 \%$ of GDP revenues should be provided out of local property taxes, leaving behind only Croatia by $0.13 \%$ of GDP; Albania is the last one for local government investments. They represent $0.9 \%$ of GDP.* 8 (Cross-Cutting Strategy for Decentralization and Local Governance 2015-2020, 2015, pg 15) 
Albania made the reform of administrative and territorial consolidation finally settling the issues of fragmentation of local units * 9 (Law no. 115/2014, "On the administrative and territorial units of local government in the Republic of Albania")

To ensure effective governance Council of Ministers of the Republic of Albania in early 2015 established the Agency for the Implementation of the Territorial Reform. The Agency will play a coordinating role between central and local government units to enable resolution of problems stemming from the process of transition to the new unified local units. The agency has not ordering functions, but will act as a guide and welfare institution for LGUs governance standards, as well as distribution of financial transition fund provided in the state budget. The Agency shall inform the institutions and other partners on the implementation progress of administrative and territorial reform.

Local government bodies are City Council and Mayor. Municipality Council members are elected according to the proportional system by direct election and represent local legislator. Mayor is elected directly by the voters of the administrative unit and exercises the executive power.

\section{The Legal Framework of Local Self Government in Albanian Speaking Countries}

Even in these countries the self-government legislation is based on European Charter of Self Government, the constitutions and laws on local self-government. In Kosovo, the government is implemented by Law on Local Governance. In eastern Kosovo, Macedonia and Montenegro it is implemented by the Law on Local Self-Government. According to the law the Communes are the basic territorial units of local government. They have the right to exercise local government. In Kosovo, the residents of administrative units have the right to elect their municipal councilors in Kosovo Municipalities by direct elections. In the first mandate they will have two years duration of action. Whereas in subsequent mandates the duration will be four years. ${ }^{\star 10}$ (Law on Local Self Government of the Republic of Kosovo, Article 37, letter 1)

In Macedonia and Montenegro the election of representatives is carried out every four years by direct elections. The Right of Citizens for Local Governance in East Kosovo Municipalities, is carried out by the Law on Local SelfGovernment, in which certain rights are provided for foreigners. * 11 (Zakon o Lokalnoj Samoupravi Republike)

Based on the study of legislation of Albanian speaking countries it has been concluded that the power of the local government is not in the appropriate level, because the central government does not delegate enough powers to local government units, as occurs in European countries, where "State delegate to Local authorities increasingly more tasks". *12 (Kval-Mellbye-Tranoi: Politics and Democracy. Prishtina, 2006, page 93).

Communes have the power to draft regulations, to adopt the Statute of the Commune, to adopt the municipal (cummunal) budget and to draw other general acts that are under their jurisdiction and govern the issues in their territory within the limits of the law defined. Municipalities (communes) in Kosovo pursuant the Law on Local Self-Government is a legal person, it has "its legal status, the right to own and manage property, the capacity to sue and be sued in court, the right to enter into contracts and the right to engage staff", and "can be owner or co-owner of a company that is in the interest of the municipality in relation to citizens". 13 (Law on Local Self-Government of the Republic of Kosovo, Article 5, paragraph 3, letter 1) Ahtisaari Comprehensive Proposal is an exception for conditions of establishment of new municipalities with Serb population in Kosovo.

In Macedonia "The commune is obliged to allow citizens access to local governance - comparative reviews basic information for services performed in the manner and conditions stipulated by statute". "14 (Zakon za Lokalnata Samouprava "Sluzben vesnik na Republika Makedonija" br. 5 od 29 januari 2002 god: Article 8, paragraph 2)

In Albanian speaking countries "Statute of the municipality (commune) is the highest act adopted by the Municipality (Commune) in accordance with the central government legislation regulating the internal organization of the Municipality (Commune)" *15 (Law on Local Self-Government of the Republic of Kosovo, Article 3)

In Montenegro, the municipality is a territorial unit in which local residents exercise the right of the Local Government. In this country there are two Municipalities (communes) led by Albanians. Ulcinj has the status of the Municipality, while the status of Tuzi Urban Municipality within Podgorica. Since the Municipality of Ulcinj has the Statute, Tuzi works and acts with Statutory Decision. Statutory Decision is the basic act of the municipality of Tuzi and has to do with defining the duties, powers, responsibilities and rights of the municipality that was established for local residents living in the territory of this urban municipality within the capital of Montenegro, namely, Podgorica.

In Presevo and Bujanovac "The basic act of the local government unit is the Statute" "16 (Zakon o Lokalnoj Samoupravi Republike Srbije, document. cited: Article 10, paragraph 1)

To meet the demands of local residents in Albanian speaking municipalities of Kosovo, Eastern Kosovo, 
Macedonia and Montenegro, and to realize their rights and obligations, they can establish enterprises and other organizations that perform public services. Thus, they have the right of cooperation and brotherhood with local government organizations both national and international of other states, with the consent of the Government. Local Government Law in Montenegro is encouraging because: "In conducting the activities of local government, In Kosovo has been a legal space that allowed the municipality according to UNMIK Regulation, 2000/45 and force them to make "arrangements with villages, settlements and urban quarters within its territory in order to ensure meeting the needs of all residents in the municipality". * 17 (United Nations - UNMIK, Regulation no. 2007/30, Doc. cited Article 5, paragraph 1). This right and legal obligation was drafted by Law in the Law on Local Self-Government of the Republic of Kosovo. *18 (Law on Local Self-Government of the Republic of Kosovo, Article 34, paragraph 1).

This may be the competences field of study to realize the cooperation with local government units in Albania with Albanian speaking countries.

At the initiative of Tirana Mayor, cooperation union was established in the municipality of Tirana, Prishtina, Gjakova, Presevo, Tetovo, and Ulcinj. This initiative should be accompanied by the Union of all Albanian speaking local government units in the Western Balkans.

The commune is independent and its rights can not be restricted to acts of state bodies, except in circumstances defined by law, in accordance with the Constitution". 19 ( Zakon o Lokalnoj Samoupravi Crne Gore, Article 8)

Macedonian legislation allows municipalities to take the decision to join tools and form joint public services, in order to realize common interests and performing common tasks within their competence. Municipality decides to cooperate with Municipalities of the Republic, the local governments of other countries and with International Organisations of local Communities and Local authorities. Municipality as a subject can join International Organisations of local governments. "International cooperation of municipalities is any act of Municipalities of the Republic of Macedonia, taken in accordance with the law, to conclude cooperation between them and local communities or local government of one or more other states, membership of their associations in international organization of local communities or government". * 20 (Zakon za Lokalnata Samouprava, "Sl. Vesnik na R. Makedonija" br. 5 od 29 januari 2002 god, document cited Article 2, paragraph 3)

\section{Conclusions}

Financial autonomy of local government still remains a challenge. Local authorities do not have adequate financial resources to perform its own functions and those delegated, especially small units of local government. Based on the data obtained about local budgets in 2012, $60 \%$ of LGUs were funded at over $80 \%$ from the state budget. Cooperation would create opportunities for the use of all human resources of municipal assets to increase the level of services in communities according to European standards. In Albania, pursuant to Article 108, communes or municipalities and districts are local government units. According to Article 108 paragraph 3 commune and municipality are units of local government. Whereas according to the law, the local government has only municipality. Legal Package should be approved for the taxation system that guarantees budget that meets the level of public services in communities, especially in the former communes. Unification of legislations in the field of competences with Albanian speaking countries. Establishment of a Union of all LGUs in Albanian speaking countries.

\section{References}

Iain Mc Lean. Political Dictionary. Tirana 2001, page 479

Article 13. Constitution of the Republic of Albania - Law 8417, dated 21.10.1998

Esat Stavileci: Introduction to Administrative Sciences. Office of textbooks and teaching aids Kosovo. Pristina, 1997, p. 247

European Charter of Local Self-Government.

Summary of legislation for local authorities in the Republic of Albania, Tirana 1998.

Law No. 8652, dated 31.7.2000, On organization and functioning of local government

Law no. 115/2014 dated 31.07.2014, "On the territorial administrative division

Cross-Cutting Strategy for 2015-2020 Decentralization and Local Governance, 2015, p 15

Law no. 115/2014, "On the administrative and territorial local government units in the Republic of Albania"

Law on Local Self-Government of the Republic of Kosovo, Article 37, letter 1

Zakon o Lokalnoj Samoupravi Republike

Kval-Mellbye-Tranoi: Politics and Democracy. Prishtina, 2006, page 93.

Law on Local Self-Government of the Republic of Kosovo, Article 5, paragraph 3, letter 1

Zakon za Lokalnata Samouprava "Sluzben vesnik na Republika Makedonija" br. 5 od 29 januari 2002 god : Article 8, paragraph 2 
Law on Local Self-Government of the Republic of Kosovo, Article 3

Zakon o Lokalnoj Samoupravi Republike Srbije, document cited: Article 10, paragraph 1

United Nations - UNMIK, Regulation no. 2007/30, Doc. cited Article 5, paragraph 1

Law on Local Self-Government of the Republic of Kosovo, Article 34, paragraph 1.

Zakon o Lokalnoj Samoupravi Crne Gore, Article 8

Zakon za Lokalnata Samouprava, "SI. Vesnik na R. Makedonija" br. 5 od 29 januari 2002 god, Doc. cited Article 2, paragraph 3 


\title{
The Psychological Violence Against Girls and Women
}

\author{
Dr. Darina Çoni-Kacollja \\ Universiteti "Aleksandër Xhuvani" Elbasan, Albania \\ Email: darinakacollja@yahoo.com
}

Doi:10.5901/ajis.2016.v5n3s1p91

\begin{abstract}
This study is focused mostly on the psychological and emotional violence against girls and women. The implementation of the study is based on the use of the quantitative research method by spreading and completing the survey with 650 respondents from 24 to 60 years old. The detailed study aims to explore the causes and conditions which favor violence as a necessity to understand the roots of these social phenomena. This implies a comprehensive analysis of social, economical, political and sub-cultural factors which affect in the implementation of it. From the data of our survey there are some results: nearly 63.0 percent of the respondents said that they had suffered psychological violence. Insults, shouts and threats are actions which happen more frequently and the respondents say that they are the most disturbing elements. Most girls and women suffer from the psychological violence within their family. This kind of violence is mainly caused by men, by their husbands, fathers, brothers.
\end{abstract}

Keywords: psychological violence, girls and women, violence within the family, husband, children, physical violence.

\section{Introduction}

The sociologist Rose Maria Calla, who is a lecturer at the University of Trento has stated that: "The psychological violence is harder to be identified because it leaves no visible traces and it can only be defined as: offences, insults, humiliation, destruction or willful damage of an object, systematic refusal to do the housework or the educational control (of children) in everyday life and as the restriction of personal freedom and movement" (Corradi, C., 2008:225). In our environments, violence is generally considered as something that is not harmful and it should be accepted in this way. People are aware of its existence not only within their families, but even in the main institutions. The psychological violence is sometimes more harmful than the physical one. Often, it is not immediately obvious. In some severe cases, it can reach up to a person's suicide.

\section{The Diffusion of Psychological Violence}

The psychological violence is the most pervasive concern in the district of Elbasan. Our survey data show that: approximately $63.0 \%$ of respondents said that they had suffered psychological violence. Insults and shouting are actions that occur more often and for therespondents they are very disturbing.

In general, the violator is the husband, the father or the brother, who exercise psychological violence against girls and women and sometimes, when this kind of violence does not work, the physical violence is used against them. Males often have been educated since childhood with this kind of behavior against girls and women, and they see this attitude as something normal in emphasizing their leading role in the family.

As emphasized by the World Health Organization (WHO): "Men exercise violence against women as a method to stop them step out of their traditionally assigned role, or when they feel that the women can be a threat to their supremacy" (Corradi, C., 2008:69).

The male, psychologically violating the female, suppresses her, by transforming her in an inferior being,who cannot react or act against this violence. In the moment that women and girls find the force and courage within to react in order to stop this violence, the male uses the physical violence, because it feels to him like his authority is being diminished. Often, after reinstating his authority, the male apologizes, saying that it will not be repeated again, but in reality the cycle repeats itself. The strategies for keeping the violated girls and women are different in different people, and it seems that they are part of the personality of the male. This is emphasized by the Italian analysts, Giuseppe Ferrari and Valentina Penati: "The strategies used by those who decide to violate another individual are cunning and aim, first of all, to make 